\title{
EDITORIAL
}

\section{A Enfermagem e os Centros Sociais Urbanos}

Na Mensagem ao Congresso em $1 .^{\circ}$ de março deste ano, o Presidente da República encarece a todos nós que façamos desernolver os Centros Sociais Urbanos. De que se trata? E assunto recente.

O Decreto n. 75.922 de $1 .^{\circ}$ de julho de 1975 , publicado no D.O.U. de 2-7-75, dispõe sobre a criação do Programa Nacional de Centros Sociais Urbanos (CSU).

Examinemos o texto legal. A finalidade do Programa é "prcmover a integração social das cidades, através do desenvolvimento de atividades comunitárias nos campos da educação, cultural e desporto, da saúde e nutrição, do trabalho, previdência e assistência social e da recreação e lazer" (Art. 1. $0^{\circ}$ ).

O Programa objetivará a instalação de centros sociais urbanos, de uso público, com vistas, principalmente, às seguintes atividades, de caráter comunitário:

\section{Educação e Cultura} cultural;

a) cursos, conferências e seminários de atualização e extensão

b) promoção de exposições, de leitura, de música, do cinema, do folclore e de outras manifestaçōes culturais e artísticas;

\section{Desporto}

III Saúde e Nutrição

a) educação sanitária;

b) imunização e controle de doenças transmissiveis;

c) assistência médico-odontológico sanitária;

d) saúde materno-infantil;

e) saúde mental;

f) saúde mutricional. 
IV Trabalho, Previdência e Assistência Social

a) treinamento profissional e orientação para o trabalho;

b) agências de emprego;

c) expedição de carteiras profissionais e assistência previdenciária;

d) assistência ao menor abandonado e à velhice;

e) assistência jurídica;

$V$ "Recreação e Lazer"

Onde serão desenvolvidas essas atividades?

$O$ art. 3.' aponta as sedes ideais, inclusive onde há conjuntos habitacionais de médio a grande porte, financiados pelo $\mathrm{BNH}$.

Com que recursos financetros serão realizados as trabalhos? Os arts. 4 e 5 respondem essa indagação. Parece que não faltarão recursos.

Os três artigos finais $6 .^{\circ}, 7^{\circ}$ e $8^{\circ}$ - referem como trabalhar. Há um Grupo Executivo coordenador com âmbito nacional.

Principalmente no item III e também participando nas atividades do item II, de encaminhamento de candidatos para cursos de formação das categorias da enfermagem, haverá oportunidade de excelente contribuição de profissionais de enfermagem. As lideranças de enfermeiros nos Conselhos $\mathbf{R e}$ gionais de Enfermagem poderão dar atenção inicial ao assunto, em cada $\mathbf{C a}$ pital de Estado, para que haja um planejamento integrado. Terão que ser devidamente aprovados os projetos de implantação e funcionamento dos centros sociais urbanos com destinação de recursos financeiros, materiais e hat manos.

O Ccordenador geral, nacional do CSU é o Representante da Comissão Nacional de Regiōes Metropolitanas e Politica Urbana (CNPU). Nós, enfermeiros, poderemos trabalhar muito bem, justamente naquilo em que acre ditamos: saúde para o povo.

Há mudanças quanto às institưições em que enfermeiros e outros exercentes de enfermagem realizam seu trabalho de saúde. Certamente os CSU eão a mais nova instituição para nossas atividades profissionais. (HGD) 